\title{
Reinforcing the Web of Municipal Courts: Evidence and Implications Post-Ferguson
}

\author{
BETH M. HUEBNER(ㄴ) AND ANDREA GIUFFRE@
}

Investigations in Ferguson, Missouri, revealed that many individuals, particularly Black people, entered the criminal justice system for relatively minor offenses, missed court appearances, or failure to pay fines. Municipal courts were focused on revenue generation, which led to aggressive enforcement of municipal codes. Although subsequent reforms were passed, little is known about whether and how the legislative changes influenced the law-in-action in the municipal courts. Using data from qualitative interviews with St. Louis area residents and regional court actors, as well as court observations, this article documents the legal structure of municipal courts in the region after Ferguson. We address how the parochial nature of municipal courts in St. Louis County perpetuates the financial marginalization of residents through the layering of punishment, and how the state legal structure further facilitates control, even after reform.

Keywords: monetary sanctions, municipal courts, policing, Ferguson, race

Misdemeanor arrests are the most prevalent form of social control in the criminal justice system and make up three-quarters of all criminal cases filed-a total of thirteen million cases each year, most for relatively minor offenses (Stevenson and Mayson 2018). The scope and implications of misdemeanor arrests came to light to many after the shooting death of
Michael Brown, a Black man, in Ferguson, Missouri, a St. Louis County suburb. An investigation by the U.S. Department of Justice (DOJ) exposed a practice of generating revenue through law enforcement, particularly the aggressive enforcement of municipal code violations, and by court actors issuing warrants for missed court appearances and payments, a

Beth M. Huebner is a professor in the Department of Criminology and Criminal Justice at the University of Missouri-St. Louis, United States. Andrea Giuffre is a doctoral candidate in the Department of Criminology and Criminal Justice at the University of Missouri-St. Louis, United States.

(C) 2022 Russell Sage Foundation. Huebner, Beth M., and Andrea Giuffre. 2022. “Reinforcing the Web of Municipal Courts: Evidence and Implications Post-Ferguson." RSF: The Russell Sage Foundation Journal of the Social Sciences 8(1): 108-27. DOI: 10.7758/RSF.2022.8.1.05. This research was funded by a grant to the University of Washington from Arnold Ventures (Alexes Harris, PI). Partial support for this research came from a Eunice Kennedy Shriver National Institute of Child Health and Human Development research infrastructure grant, P2C HD042828, to the Center for Studies in Demography and Ecology at the University of Washington. We thank the faculty and graduate student collaborators of the Multi-State Study of Monetary Sanctions for their intellectual contributions to the project, as well as, Joseph Schafer for feedback on this paper. Direct correspondence to: Beth M. Huebner, at huebnerb@umsl.edu, UMSL, One University Blvd., St. Louis, MO 63121, United States.

Open Access Policy: RSF: The Russell Sage Foundation Journal of the Social Sciences is an open access journal. This article is published under a Creative Commons Attribution-NonCommercial-NoDerivs 3.0 Unported License. 
practice commonplace in the region. In 2013, a little over 20 percent of the city of Ferguson Missouri's total revenue came from the payment of legal financial obligations (DOJ 2015). Josh Page and Joe Soss $(2017,142)$ contend that "what the DOJ discovered in Ferguson is not exceptional in relation to the past or present of US governance." They characterize monetary sanctions as financial predation of marginalized communities - stemming from a long history of race and class control sustained in an era of neoliberal governance. Aggressive enforcement, particularly of lower-level offenses, unduly affects Black people, who were more likely to be stopped and arrested by police, had longer case processing times, were required to make multiple court appearances, and have their cases lead to a warrant (Ferguson Commission 2015).

Scholars and policymakers have written broadly on the use of monetary sanctions in Ferguson and elsewhere (DOJ 2015; Harris 2016; Rios 2019). This work adds to previous writing in several ways. First, we seek to address how the legal structure of municipal courts in St. Louis County influences justice in the context of monetary sanctions. We deepen the work on legal financial obligations, or LFOs, by considering small contacts with the justice system, whereas much of the foundational work in this space has been conducted with felony courts (Harris 2016). Particularly, we consider how the parochial nature of the municipal courts has assisted in the maintenance of monetary sanctions as a broad system of control past the writing of the Ferguson report and passage of associated reforms. Secondarily, we document how state legal structures further perpetuate the cycle of control and extend and deepen the consequences of a criminal conviction, particularly for people of color and individuals with fewer economic means.

To do so, we draw on data from interviews and court observations to examine how individuals with legal debt and court actors characterize their experiences with the municipal courts in the St. Louis region in the context of monetary sanctions. We describe how the independent structure of the municipal courts in the St. Louis area facilitates the need for revenue generation tactics such that individuals liv- ing in poverty and persons of color get trapped in a revolving door of misdemeanor justice, a phenomenon deemed the muni-shuffle. We define the muni-shuffle as the process by which parochial governance fosters low-level, routine interaction with the police and courts and sustains such contact by limiting remedies for resolving debt, including the monetization of legal representation, and fragmenting information flow between municipalities and to citizens. Municipal sanctions, primarily traffic tickets, unduly target and affect people with fewer economic means and people of color (Hepburn, Kohler-Hausmann, and Medina 2019), and the associated sanctions and conditions of compliance tether people to the system (Harris, Evans, and Beckett 2010; Pattillo and Kirk 2021). We contend that the lack of oversight on the part of the state combined with the individualistic, racialized construction of municipalities has allowed these systems of control to continue since Ferguson.

\section{MISDEMEANOR JUSTICE AS CONTROL}

The past three decades have seen a growth in the number of municipal and ordinance citations issued (Stevenson and Mayson 2018; Mayson and Stevenson 2020), which come with fines and fees attached (Harris 2016). The system of misdemeanor justice is far reaching and extends the penal sphere to significant numbers of the population (Kohler-Hausmann 2018; Natapoff 2018). This system is unique because most people have had contact with these courts, unlike felony courts, often because of traffic and ordinance offenses; many can afford to pay their monetary sanctions promptly. In fact, new online payment portals allow those with economic means to bypass the system altogether (Bing, Pettit, and Slavinski 2022, this volume). Those who cannot pay in a timely manner confront opportunity costs including extended system contact, additional financial assessments and legal penalties, and associated time costs and procedural hassles, all of which can further the inequities of this system of sanctions (Colgan 2018; Martin, SpencerSuarez, and Kirk 2022, this volume).

The sheer volume of cases and what is perceived by many as low-stakes proceedings limits targeted legal reform as well as scholarly and 
public attention to the discriminatory practices within the system (Mayson and Stevenson 2020). Monetary sanctions can be extracted "in plain sight" with the full participation of the court and thus can further control and humiliate marginalized populations under the pretense of law (Pattillo and Kirk 2020, 76). Mary Pattillo and Gabriella Kirk (2021) describe how court actors use the law and profusion of penal power to legitimate the chastisement of individuals with fewer economic means and threaten them with incarceration for nonpayment of monetary sanctions.

Although the initial amount of monetary sanctions assessed may be small and burden those with fewer economic means financially (Harris 2016), it is the process of attending court and being marked and shamed repeatedly that is also punitive in nature (Feeley 1979). In the courtroom, the onus is on the person who cannot pay monetary sanctions to prove that he or she is compliant rather than on the state to recognize differing abilities to pay (Page and Soss 2017). Compliance with the misdemeanor court system is performative and extracts costs that extend past the financial sanctions owed and tether individuals to the system (Martin, Spencer-Suarez, and Kirk 2022, this volume). This population is sorted, tested, and regulated (Kohler-Hausmann 2018). Individuals must undertake a significant burden to comply with formal legal proceedings. Transportation challenges, incomplete information about court appearances, childcare, and employment can be barriers to court attendance (Zettler and Morris 2015; Cadigan and Kirk 2020; Garrett, Modjadidi, and Crozier 2020). Transportation can be particularly challenging given that some courts suspend driver's licenses for unpaid economic sanctions or failure to appear in court (Martin et al. 2018; Shannon et al. 2020). When individuals get a ticket they cannot pay, it is common for courts to put them on a payment plan under which they must make recurring appearances (Huebner and Shannon 2022, this volume; Pattillo and Kirk 2021). Consequently, individuals who cannot pay their monetary sanctions become "tethered" to the system (Harris 2016) or kept on an "invisible leash" (Pattillo and Kirk 2021).

Overall, monetary sanctions on their face appear benign and neutral but in fact reinforce bias in their execution (Bell 2017). The increasing imposition of monetary sanctions further entangles those with fewer economic means in the criminal legal system, and sneakily reinforces racial and class inequalities by regulating quality of life (Harris, Evans, and Beckett 2010; Harris 2016). Individuals with fewer economic means are doubly taxed through government seizure related to criminal legal system operations and the procedural hassles associated with compliance that fuel racial disparities (Fernandes, Friedman, and Kirk 2022, this volume; Slavinski and Pettit 2021).

\section{PAROCHIAL GOVERNANCE}

The costs assessed by justice systems have grown exponentially in recent years, particularly during periods of financial austerity for local governments (Fernandes et al. 2019; Graham and Makowsky 2021; Kirk, Fernandes, and Friedman 2020). As state and local budgets and financial reserves declined, many communities focused on revenue generation by increased use and costs of monetary sanctions, costs that were predominantly assessed by municipal courts and local police departments (Martin 2020; Slavinski and Pettit 2021). For example, evidence indicates that communities use measures of police officer productivity tied to the number of citations issued as a way to fund local operations; a phenomenon documented in the Department of Justice's (2015) investigation into the Ferguson police department, but part of local governance in the United States for many decades (Page and Soss 2017; KohlerHausmann 2018; Natapoff 2018).

The parochial nature of communities further facilitates the hidden nature of control and the rise of monetary sanctions. Scholars argue that municipal governments are critical instruments of control and produce racial disparities (Page and Soss 2017; Rios 2019). It is not the fragmentation of communities that is a problem per se, it is the economic and political structure of municipalities that have in practice led to disparate outcomes for individuals across many domains, including the criminal legal system. The process occurs in a few phases. First, the fragmentation of communities within a region means that substantial competition 
for often very limited resources. In this patchwork governance, resources are often accumulated in a small set of more affluent locales, often wealthy White suburbs, that further disadvantage other communities and lead to greater racial segregation (Gordon 2013, 67).

In addition, the new economic structure also often requires communities to raise funds for local services. The ability to generate revenue varies widely and often favors White, suburban locales. In Missouri, municipalities can keep sales taxes that are generated locally (Gordon 2013). Local funding structures lead to inequalities in local services because less affluent municipalities have less of a tax base from both residents and commercial businesses (Pacewicz and Robinson 2021). The sociologists Josh Pacewicz and John Robinson (2021) call for an understanding of the racialization of municipal opportunity-highlighting the unequal ways in which White and Black majority suburbs operate fiscally. Middle-income, White suburbs are often located next to hyperwealthy White suburbs, giving them an opportunity to appeal to business investment while drawing revenue from local property taxes. On the other hand, middle-income Black suburbs are typically adjacent to lower-income Black suburbs, reducing their ability to attract commercial business and revenue from local property taxes. What follows is that the White suburbs grow and Black suburbs frequently fall short of necessary municipal operating budgets. Thus Black suburbs turn to fines and fees to make up for what they lack in investment and property taxes. This reliance on fines and fees reproduces racial disparities because those who have less income in the first place are targeted by their communities for revenue extraction (Pacewicz and Robinson 2021). Similarly, the criminologists Shytierra Gaston and Rodney Brunson (2020) find that police officers in St. Louis engage in highly discretionary activities such as proactive traffic and pedestrian stops in majority Black and racially mixed neighborhoods. People of color are more likely to be stopped in these neighborhoods, and police justified these stops based on perceived criminogenic conditions of the community. Evidence indicates that predominantly Black municipalities extract revenue from their citizens through "formal and infor- mal practices that appear rational and routine" but are fundamentally unequal in their application (Rios, 2019, 236). Overall, evidence indicates that the racial patterns of policing and revenue extraction remain extreme in suburban communities, especially in those with larger groups of people living under the poverty level (Beck 2019), a higher proportion of Black residents and individuals who voted for Republican candidates, or larger police forces (Slavinski and Pettit 2021).

At the individual level, scholars have suggested that a new parochialism has afforded legitimacy to surveilling young people of color. When municipalities lack dense private-level ties, private citizens tend to rely more on public institutions, like the police, to address social problems. New parochialism, therefore, represents a blending of parochial and public social control in that private citizens rely on public agents to address crime and "disorder" (Carr 2003; Becker 2014). Community members pressure police to address problems of disorder by using language that invokes an image of a person of color without talking about race directly (Boyles 2015). Without addressing their implicit racism, White people thus frame people of color as dangerous or criminally prone (BonillaSilva 2010).

This color-blind rhetoric legitimizes disproportionate police contact with people of color and increased police contact legitimizes White citizens' concerns about alleged disorder, promoting a feedback loop of control (Carr 2003; Becker 2014). For example, the sociologist Andrea Boyles (2015) notes that police routinely surveil young Black men hanging out in public places and target them based on extralegal characteristics stereotypically associated with deviance (such as clothing like sagging pants and hairstyles such as dreadlocks). Police then justify disproportionate contact with people of color for obscure code violations by relying on "color-blind" rhetoric and the White public's support (Becker 2014). Order maintenance policing by enforcement of code violations continues to criminalize an entire population of young, Black men simply for existing (Boyles 2015). As stated in the Ferguson report (Ferguson Commission 2015), a key part of misdemeanor justice is undermining trust as well 
as cultivating fear and avoidance of public authorities in communities of color, not necessarily just advancing fines and fees. We argue that parochial governance fosters initial contact with police and prompts people with fewer economic means, and especially people of color, to get trapped in the municipal court system.

\section{STUDY SITE}

St. Louis County is characterized by parochial governance and is an ideal case study for the broader understanding of localized systems of justice. Missouri courts are divided into three levels: circuit courts, appeals courts, and the Supreme Court. Circuit courts adjudicate misdemeanor and felony criminal cases as well as civil matters, and municipal courts, which often focus on traffic and city ordinance violations, are divisions of the circuit courts and are subject to local rules. St. Louis County has eighty-eight municipalities-eighty-three of which have independent courts to enforce municipal codes and local ordinances-and more than fifty independent police agencies or collaboratives (Missouri Attorney General 2020). ${ }^{1}$ The state of Missouri has the fourth highest number of municipalities (944) of all fifty states and the District of Columbia. Illinois, Texas, and Pennsylvania each have more than a thousand, suggesting that this phenomenon is not geographically unique. The average is 382 (Census Bureau 2017).

\section{Racialized History of the}

\section{Criminal Legal System}

The localized structure reflects the racialized history of the St. Louis metropolitan area. In 1876, St. Louis City and St. Louis County separated into two discrete counties, which began the process of White exodus and fracturing of the region. The parochial structure of St. Louis County accelerated after 1943, when ninety-two municipalities were established in St. Louis County during an eleven-year period and state law allowed for independent police departments and courts. The area is also known for its "redevelopment" or "blighting" plans, which aimed to increase real estate values by downsizing or razing historically Black enclaves. At the same time, many highways were built in place of these enclaves and some municipalities banned multifamily units and blocked off roads (Johnson 2020). Thus the St. Louis Metropolitan region has been historically racially segregated, which has been furthered by the incorporation of predominantly White municipalities, zoning regulations, and gerrymandering of school districts (Gordon 2019). Because fewer local resources were available to draw on, decline and disinvestment began to plague the predominantly Black and economically challenged northern communities in St. Louis County, and courts have had to pick up the deficits to generate revenue in the absence of local property and sales taxes (Gordon 2019).

Evidence, most notably the investigations conducted in Ferguson, is considerable that Black people are disproportionately stopped by police (DOJ 2015), and this practice continues. In 2019, the Ferguson Police Department reported that the disparity index in police stops, measured as the proportion of stops to proportion of the population, as 1.44 for Black people and 0.24 for Whites people (Missouri Attorney General 2020). The use of warrants in the region is also commonplace; 150,423 warrants were issued in St. Louis County in 2019 (Office of State Court Administrator 2020). Black people were just over four times more likely to be arrested for a bench warrant than Whites, and most warrants were issued for failure to comply with an ordinance violation that includes traffic offenses, minor drug charges, and vagrancy, among others (Slocum, Torres, and Huebner 2020).

\section{LEGAL REFORMS}

Revisions to the Missouri statutes have influenced how monetary sanctions are imposed in municipal court. Responding to the events in Ferguson and the ensuing Department of Justice investigation, reforms enacted in 2015 were intended to increase oversight of municipal courts; limit municipalities' ability to generate revenue from citizens in the form of fines, fees,

1. For a list of municipal courts, see "Municipal Court Contact Information," https://wp.stlcountycourts.com /municipal-division (accessed August 7, 2021). 
and bond forfeitures; and lessen the overall financial burden of monetary sanctions on Missourians (see also Smith, Thompson, and Cadigan 2022, this volume). One of the most significant changes was restricting the maximum amount for a fine and reducing the percent of the city's budget that could be derived from fines and fees from 30 percent to 20 percent. ${ }^{2}$ However, this change was largely symbolic given that the City of Ferguson during this time collected about 23 percent of itsr general fund from economic sanctions (DOJ 2015); therefore, the legislation mandated very little substantive reform in enforcement practices. Other changes include capping fines and fees for minor traffic violations at $\$ 225,{ }^{3}$ barring court costs for indigent defendants, and mandating community service as an alternative to financial payment.

Despite these new standards, scholars have pointed to the burden of even relatively small monetary sanctions, alluding to the harsh consequences for nonpayment (Pleggenkuhle 2018). In the analysis that follows, we denote that simply reducing the dollar amount assessed does not mitigate the multiple jurisdictional entanglements nor preclude courts from issuing warrants for failure to appear. We argue instead that it is the economic and social features of the region that fuel the need for revenue generation and the court and legal structure of the state prevents adequate legal representation and remedies for resolving debt, and fragments information flow, ultimately leading to inequitable outcomes and increased state control.

\section{METHOD}

Our analyses address, first, how the legal structure of municipal courts in St. Louis County and the broader legislative structure of the state influence the imposition and collection of monetary sanctions in municipal courts and, second, the consequences of this structure for individuals, particularly for those who do not have the financial ability to comply.

\section{Data}

Data come from interviews with court actors and individuals with legal debt and are supplemented with observations of court proceedings. Data were collected as part of a larger project on monetary sanctions (Harris, Pattillo, and Sykes 2022, this volume). Data collection began in 2016, shortly after the Missouri legislature enacted the noted legal reforms. We interviewed thirty-seven individuals with current legal debt from the metropolitan St. Louis region, recruited several ways, including flyers posted on Craigslist and Facebook and referrals made by local social services agencies and state probation and parole offices. Consistent with local demographics and the population of people with monetary sanctions, the sample predominantly included Black men. In total, 75 percent of the sample were Black, and the remainder was evenly split between individuals who identified as White, Asian, and Multiracial. Males made up 84 percent of the sample.

We also interviewed twenty-five court actors (four defense attorneys, two prosecutors, eight judges, three clerks, and eight probation officers) from the greater St. Louis area and conducted more than ninety hours of court observation from the St. Louis circuit and municipal courts. All but three of the court actors were White, and a little more than half were women. We assigned each of the individuals with legal debt and court actors a unique pseudonym. Court actors were recruited using multiple methodologies. At the onset of the study, the researchers made lists of all judges and directors of the local probation and parole offices and the lead public defender and prosecutor. All local judges were invited to participate. Division leaders were contacted to request participation as well as approval to contact other agency staff, including clerks. The researchers developed a rapport with court actors by spending time in court buildings and correctional facilities over several years. Court actors were solicited in person, by phone, or by email to participate in the project. At the same time, 
Figure 1. Framework of Control

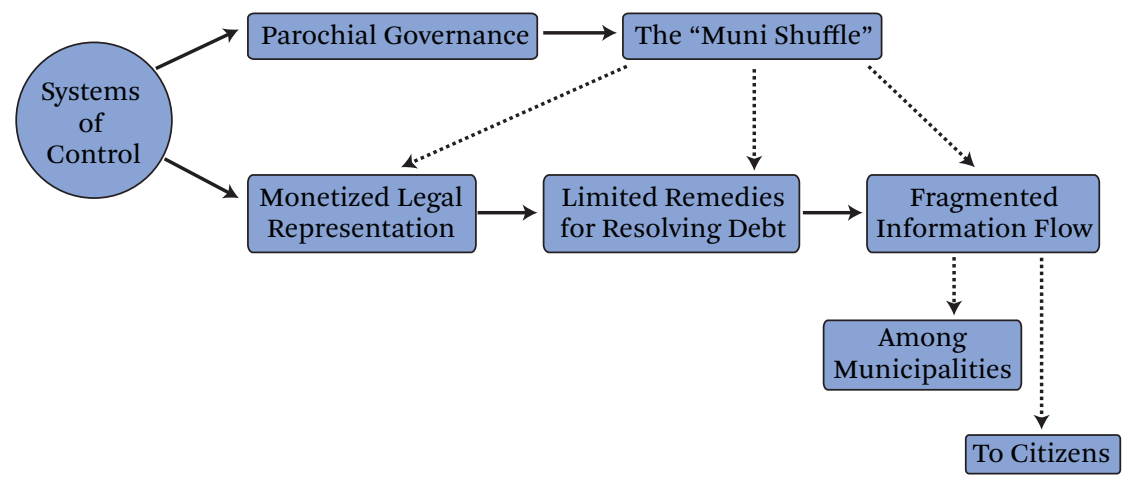

Source: Authors' tabulation.

given our rapport with some individuals, we used a snowball methodology to contact other court actors (Biernacki and Waldorf 1981). We also used snowball sampling in sending cold emails to court actors around the St. Louis region to request interview participation and to ask for recommendations for other court actor interviews after the initial interviews were completed. Multiple entry points were used to increase sample diversity and reduce the potential for selection bias in the resulting sample (Atkinson and Flint 2001). ${ }^{4}$

\section{Analysis}

We used a semi-structured interview guide to frame our conversations with individuals with lagal debt and court actors (Harris, Pattillo, and Sykes 2022, this volume). The interview protocols allowed for ample elaboration on personal experiences with the justice system and how individuals viewed the process of assessing monetary sanctions. Keeping with a constructivist grounded theory methodology, we focused on how individuals were embedded in larger structures, networks, and relationships (Charmaz 2006).

Taking the sensitizing concept of "systems of control" as a starting point for our analysis (Blumer 1954), we sought to understand how monetary sanctions were structured and as- sessed in the post-Ferguson era. Accordingly, we selected particular codes from the codebooks for court actors (monitoring LFO payments, court structure), individuals with legal debt (confusion; discrimination, prejudice, and stigma; failure to appear; multiple jurisdictional entanglements; neighborhood; police and policing; transportation; warrant), and field notes (bail, bond setting, consequences for nonpayment, defendant confusion, descriptions of courtroom, reprimand or accountability, suspended license, multiple jurisdictional entanglements). A keyword search was also conducted on the word Ferguson.

We developed analytic memos using a modified axial coding framework with systems of control at the center of the axis. The sociologist Kathy Charmaz (2016) describes how axial coding can be used to better understand the relationships among emerging categories and themes in qualitative data. However, rather than imposing a predetermined structure of categories and themes around one axis, we used this strategy as a loose guide to map emerging information. As we learned about experiences represented by the themes, we used the modified axial coding framework to link and develop subthemes. Figure 1 presents the relationships among themes.

We used the constant comparative method

4. We faced particular challenge in recruiting attorneys. Despite repeated requests for interviews, attorneys did not respond to our solicitation. Interviews with individuals with legal debt and court actors lasted about an hour and took place at local state-run offices, libraries, local restaurants, and coffee shops. Institutional Review Board (IRB) approval was sought and granted from the University of Missouri-St. Louis. 
Figure 2. Municipal Courts in Saint Louis County, Missouri

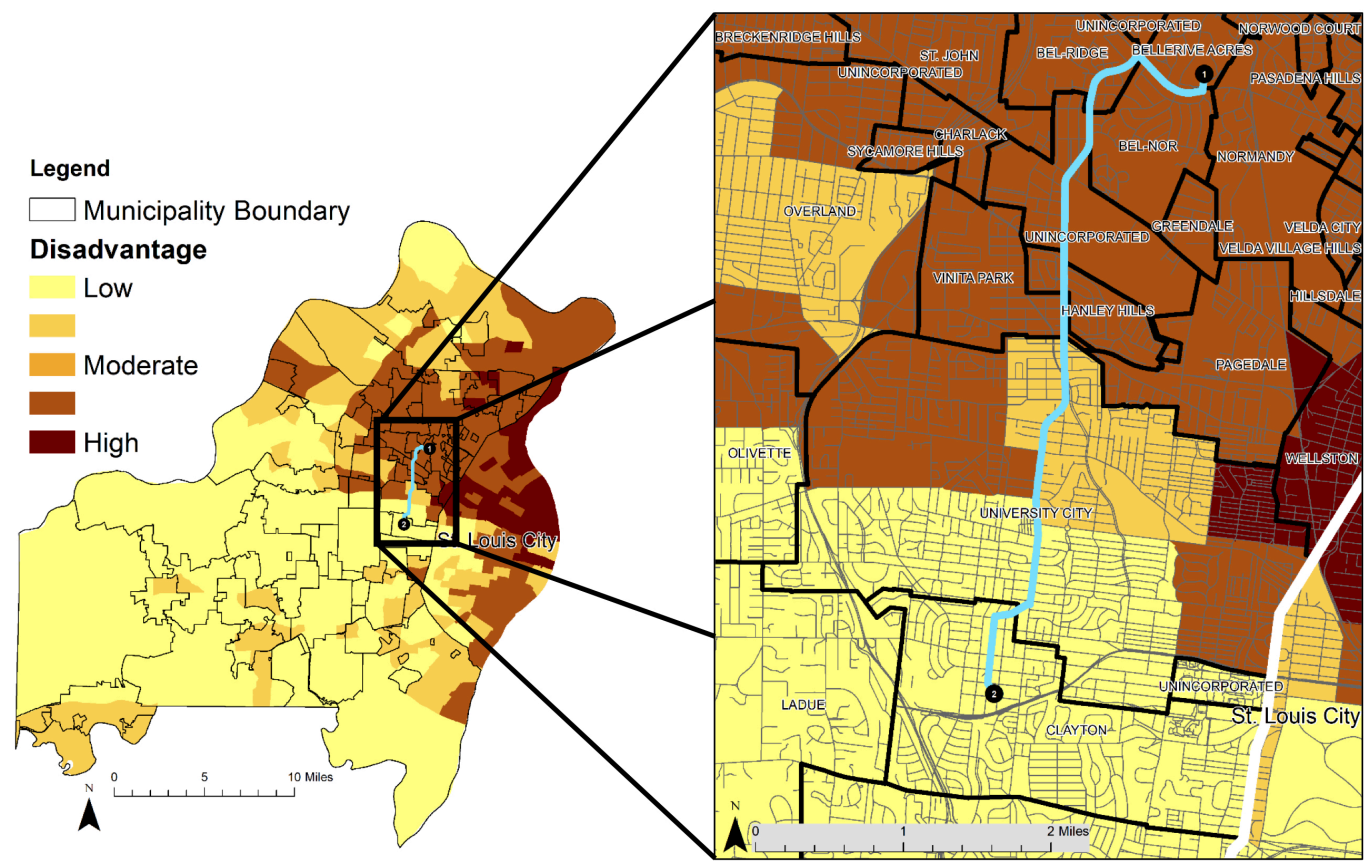

Source: Authors' tabulation.

to search for evidence that would disconfirm the patterns in our data or deviant cases and looked for similarities both within and across interviews and field notes (Glaser and Strauss 1967; Charmaz 2006). Even though the information presented in this project cannot be generalizable to a broad population, the depth and detail of qualitative analysis provide a theoretical lens through that we can link systems and control and monetary sanctions. Rather than make claims about the causality of a particular phenomenon, we seek to understand the processes by which monetary sanctions gained and maintained control in the St. Louis area.

\section{SYSTEMS OF CONTROL}

The profit-focused and parochial nature of the municipal courts in the greater St. Louis region has led to systems of control that unduly affect individuals living in poverty and persons of color. We begin our analysis with an explanation of how decentralized municipal courts extract monetary resources through traffic stops and warrants.

\section{Profit and Parochial Governance}

Figure 2 illustrates the parochial structure of St. Louis County. The route marked on the map is a typical one from the Ferguson region to the county seat in Clayton. It runs 5.48 miles and passes through six communities, each with an independent police department and court, and an unincorporated area. The drive takes approximately nineteen minutes by car and eighty minutes by bus. Limited public transportation in the region makes driving the preferred way to travel.

The numerous independent law enforcement agencies in the region increases the opportunity to come in contact with the police. Police in the region routinely pull over and ticket individuals for traffic violations or as part of a pretextual stop, often for perceived seatbelt violations. Many of these infractions involve crimes that are tied to vehicle maintenance, such as a broken tail light. Individuals must pay a poverty penalty, by way of traffic citations, because they lack the means for routine car maintenance (Harris 2016). Despite some decline in misdemeanor traffic arrests in some parts of 
the region after the reforms, racial disparities in enforcement remain (Slocum et al. 2020). Those who do not have the resources to comply are saddled with the legacy of harsh local enforcement.

Because of the parochial nature of the region, participants commonly reported that they had multiple infractions, largely related to traffic offenses, across municipalities, all for the same violation. Isaiah, a twenty-one-year-old Black male described how he had "had to go to seven places at one time" to address traffic infractions related to speeding, which he deemed the "world tour." Probation Officer Phillips indicated that "more than half" of his caseload had multiple municipal cases that have not yet been resolved.

Municipalities are also allowed to enact special zones in concert with the Missouri Department of Transportation. ${ }^{5}$ In these zones, associated fines are doubled as a means of revenue extraction. The statute is vague, stipulating that a highway safety analysis must show that the area has a greater number of fatal or disabling. car crashes than other comparable roadways. ${ }^{6}$ Probation Officer Turner described how one agency designated a region of the local highway, a popular thoroughfare, as a safety zone: "You drive down the inner belt and you're going through all these different places and every one of them can ticket you for what have you. The doubling and the tripling of the fines, you go by the airport and you go too fast on 70 by the airport, it's designated as a safety zone and they triple the fine. It's like, really? So, the ability to enforce your own regulations I guess that doesn't seem to be fair." He was concerned that municipalities' power goes unchecked, where laws may unfairly target individuals as part of a revenue-generating strategy. Probation Officer Phillips further explained that the majority of individuals targeted by these laws have a lower income: "You see folks that have when we run their record check, they've got half a dozen things from different small municipalities that are just hung there because they can't get them closed out because there's a cost associated with it." The discretion is afforded to police and courts unduly burdens those without sufficient economic means to comply, which helps perpetuate racial inequalities (Bing, Pettit, and Slavinski 2022, this volume).

The widespread use of bench warrants in the region extends control, further entrapping people without the means to pay. Although warrants can no longer be issued for failure to pay in municipal court, judges can issue failure to appear warrants if an individual misses their court date. In this way, failure to appear becomes failure to pay. The sheer number of warrants executed by municipal judges in the region is large and continues despite reforms (Slocum, Torres, and Huebner 2020). For example, the City of Pagedale, with a population of 3,295 , issued 3,666 warrants in 2019, a per capita rate of 1.11 (Office of State Court Administrator 2020). The city is 92 percent Black and the police department is under a consent decree.

In addition, recent legal reforms that remove or reduce sanctions for moving violations do not address old warrants or tickets; the legacy of the earlier court systems therefore continues. For example, Attorney Thompson described the frequency and enduring nature of municipal and traffic offenses for his clients: "Most of my clients, demographically speaking, would be Black males, probably between 20 to 35 I would say." He then noted, "It is very rare for a client to come into my office and not have six municipalities that they have to deal with and a lot of times they didn't even know it. Then I'll run their DOR [Department of Revenue] report and they have holds in three other places. Then I call those places and they're like, 'He owes us $\$ 700$ from 1982 and we still want our money." He contended that the municipal courts are less interested in justice and more focused on revenue, a theme echoed by Probation officers Phillips and Turner.

Warrant checks are often triggered during a routine traffic stop. Many participants, particularly people of color, reported that they were pulled over for probable seatbelt violations or other minor infractions, and many felt that they

\footnotetext{
5. For more information, see Missouri Department of Transportation, "Travel Safe Zones," https://www.modot .org/travel-safe-zones (accessed August 8, 2021).
}

6. RSMo 304.590. 
were targeted by the police because of their race. ${ }^{7}$ Noah, a twenty-nine-year-old Black male, described being profiled by police as someone with outstanding warrants, a theme echoed most often by Black participants. Noah's license was suspended for failure to pay child support. He contended that when police see him driving, they pull him over and check for warrants, which can start a cycle of incarceration and warrants for failure to appear in other municipalities. He argued, "So every time they see me they flag me. And they be like, they tell me, 'You got six warrants.'” Similarly, Jayden, a twenty-year-old Black male, indicated that he was "harassed a lot in the county." He described how he was pulled over because a police officer could not read his temporary license plates. One recent experience was when he driving in his community, a predominantly Black neighborhood: "I rode past a police officer. He looked at my car and I had a hood on and I still had my uniform on. He went down the street, turned around and sped up to catch up with me. I told my little sister, I'm like, 'They going to pull me over, watch.' When I was getting ready to change lanes he cut on his lights. He walked to my car. He said the reason I pulled you over was because I can't read your temps."

Both Jayden and Noah were pulled over on suspicion of a crime. Many municipal and ordinance violations are a reflection of order maintenance policing and confer police with immense discretion. Infractions, like a potential seatbelt violation that comes with a $\$ 10$ fine, are passed under the guise of safety. However, in application, this ordinance provides an avenue to target people of color, as police officers only have to perceive the absence of a seatbelt to make a traffic stop. This finding is consistent with research of this type that finds that lawmakers use words like disorder, safety, and quality of life to describe symbolic assailants, which justifies police and court contact with people of color (Boyles 2015). These laws allow municipalities to predatorily extract resources from citizens by repeatedly stopping on the suspicion of minor traffic offenses that may start a cycle of returning to court to pay off debt and when individuals miss court dates, and reveal additional warrants. On its face, the reforms are neutral in their development. In application, however, the police and the courts have discretion that unduly affects those without the economic means to comply, which further perpetuates racial inequalities (Bing, Pettit, and Slavinski 2022, this volume).

\section{THE MUNI-SHUFFLE}

The decentralized and profit-focused nature of the municipal court system and the preponderance of tickets and associated warrants lead some to become further entrenched in the system. Several participants remarked on the muni-shuffle, whereby routine contact with the police can further deepen control, a consequence imposed most often on people of color and those with less economic means. The shuffle often begins with a small infraction but can escalate if one is ticketed by multiple jurisdictions and a warrant is issued. The process then becomes a revolving door of contact that is difficult to escape. Attorney Roberts described the process: "If it's a broken tail light, and they run through St. Charles Rock road, it has four different municipalities. They get pulled over by each municipality. They will shuffle you once you take care of business in one county, if you were to get arrested on a warrant, you go to the next county, and the next county, and the next county until you're released."

The cycle of entrenchment in the municipal court evolves in several phases. First, individuals enter the municipal court system for a minor crime, most often a traffic or driving-related offense, because these courts have the legal authority only to adjudicate misdemeanors and ordinance crimes. Those who have the financial means to comply are, for most offenses, able to pay the fine with the clerk in person or online and have no further involvement with the court. Those who do not have the means or who would like to contest the charge are required to attend court for a hearing. Attorney Thompson explained:

There's eighty-one little bitty courts in a very small area so people are getting ticketed for the same problems with their car over and 
over, and over again. That is a systemic thing as opposed to how much money everybody is charging. If you had a tail light out and the fee was $\$ 100$, maybe. You got a ticket in St. Louis County, let's assume there's only one St. Louis County Court. If you got a ticket there for $\$ 100$, and you were able to pay that back in \$25 month increments, that might not be too bad but instead with your taillight, you've got a ticket in [three communities that have predominately Black residents]. You've driven five miles to restrictive North County and you've gotten a ticket for the same thing over, and over, and over again. That's exacerbating the problem.

He contended that the nature of the problem extends beyond the cost of the legal financial obligations. Because municipalities are ticketing individuals over and over for the same offense, the problem appears organizational and unduly affects people with fewer economic means. Even though the initial ticket may not pose a large burden, being ticketed multiple times across municipalities quickly balloons the cost and further solidifies the tether to the system (Martin, Spencer-Suarez, and Kirk 2022, this volume).

When asked why they believe that individuals in the more affluent communities are less likely to have outstanding obligations to municipal courts, Probation Officer Roberts replied, "I think it comes down to income. I think we get into areas where the median income is lower and the unemployment rate is higher and you just got people that get stuck." He emphasized, like Attorney Thompson, the systemic nature of the shuffle. Individuals get caught in a web of fines and fees, and potentially warrants, that become unwieldy, if not impossible, to resolve.

Entanglement in the municipal court system continues if individuals are not able to pay because they must return to court to enter into a payment agreement and continue to attend court until the sanction is paid in full. Individu- als who miss more than one court date can be issued a failure to appear warrant that mandates appearance in court and authorizes arrest. Attorney Roberts elaborated: "Like what happens is that if you get a number of these tickets, you get these tickets then go to warrant, then they get your license, and then of course your insurance is super high, so you can't afford it."

Finally, the shuffle begins if individuals accrue multiple sanctions across courts. Individuals must shuffle from municipality to municipality to attend court, pay monetary sanctions, and attend to other conditions of compliance. Individuals are required to settle warrants separately in each court, because the court system is not unified, which further extends entanglement. Compliance with court orders requires regular transportation and having the time to attend hearings. Each hearing comes with procedural hassles that compound the challenges of compliance (Kohler-Hausmann 2018; Cadigan and Kirk 2020).

Probation Officer Phillips described the same pattern wherein a traffic infraction can lead to substantial consequences: "If they don't pay those traffic fines or if they don't show up to the traffic court, they're going to lose their driving privileges. And it mushrooms into being an issue being where then they pick up a driving while revoked. And then, they pick up multiple while revoked. And then, we see people come on supervision for driving while revoked. And that's the cycle that really is uncomfortable from this point of view."

The cycle of municiple court involvement can be further complicated by the loss of a driver's license. By statute, individuals in Missouri who fail to appear in municiple court on traffic charges involving moving violations or who have enumerated points for law violations will have their license suspended, and licenses can be barred for renewal for failure to pay. ${ }^{8}$ As part of the reforms, driver's license suspension and renewal cannot be barred for minor traffic violations, classified as not having an accident or injury. ${ }^{9}$ However, individuals who can hire an 
attorney can get amendments to the number of points assessed against their license, making revocation less likely, whereas those who cannot pay are not typically offered such remedies (Arch City Defenders 2014).

By way of example, Antonio, a twenty-fouryear-old Black male, explained that he had been cited for driving with a suspended license an estimated, "four or five" times and had accrued warrants in municipalities. He accumulated enough points on his license for it to be suspended: "A couple of nonmoving violations that I had and the tally points, obviously, up against my license until they had to suspend me. After you get charged with so many traffic offenses, your license gets suspended. I probably did it up on myself, not driving the best of cars, but just trying to use what I had. It was usually just me driving a raggedy car that honestly got me in a situation."

Like many participants, he did not have the financial ability to purchase a new car and was regularly tagged for traffic and ordinance violations, including a citation for a broken tail light. He did not have a valid license at the time of the interview. When asked why, he noted that he was "just putting it off because I felt like I didn't have the money to actually pay the tickets off or pay off the court fees or the fines" and that he did not drive any longer because of the infractions.

Enforcement practices, coupled with the lack of representation, clearly widen disparities. Antonio's inability to keep up with car maintenance and failure to pay the resulting tickets led him to lose his driver's license. Because he did, he could not legally drive to work in an area that offered little public transportation. We argue that individuals with legal debt like him become trapped when they cannot afford to pay for car maintenance or are stopped on suspicion of a crime or other pretextual reason, acquire tickets in multiple municipalities, and then lose their driver's license so that they cannot legally drive to work and make money to pay off their legal debt or drive to court to resolve the debt. Individuals enter this cycle largely because of poverty that is further perpetuated by the parochial nature of the municipalities, which makes escaping the revolving door of monetary sanctions inordinately difficult.

\section{EXTRA-LOCAL CONTROLS}

\section{IN AN ERA OF REFORM}

Despite municipal court reforms following the Ferguson investigations, the presence of state law that upholds the independence of courts and the concomitant lack of oversight of the courts further perpetuates the cycle of control. The hands-off nature of the legislature also allows the police great discretion and can lead those with fewer means and less power, particularly people of color, to be harshly punished based on their lack of access to state systems (Garland 2001; Wacquant 2009). Despite reforms, the state has continued to abdicate control of the municipal courts and has maintained the practice of placing the onus for funding representation and finding information to the client, which further increases the disproportionality of municipal and ordinance charges.

\section{Monetized Legal Representation}

The right to counsel is a central element of a fair legal system; however, access to representation in Missouri municipal courts depends on the ability to pay. In Missouri, individuals who enter the municipal courts are not eligible for a public defender because the Missouri Code of State Regulations mandates services to be provided only to individuals charged with a felony. ${ }^{10}$ Individuals with municipal cases must hire a private attorney or represent themselves, which leads to a disproportionate cost to litigants. The state places the obligation to find and fund represen-

9. RSMo Section 479.350 describes the categorization of minor traffic offenses. Minor offenses cannot include an accident or injury. Offenses for driving more than nineteen miles over the speed limit or for exceeding the speed limit in a school or construction zone are not considered minor offenses.

10. Missouri 18 CSR 10-2.010 (Definition of Eligible Cases) makes this determination. For more, see Missouri State Public Defender, "How to Apply for Services," https://publicdefender.mo.gov/clients-and-families/how -to-apply-for-services (accessed August 8, 2021). 
tation on the litigants rather than recognizing the need for representation and providing access to justice (Page and Soss 2017).

The decentralized nature of the multiple court system makes rectifying tickets more daunting for litigants and attorneys alike, which amplifies the potential negative outcomes for people without economic means to hire an attorney. Defense attorneys commented on the arduous process required to resolve debt in multiple municipalities. Defense Attorney Thompson said that he would "have a person with municipal tickets on my docket for a yearand-a-half just waiting for them and helping them and encouraging them and tracking their stuff." Further, he explained, "People are afraid of that process and I think with good reason, so that process doesn't always happen for folks that aren't represented or who aren't represented by a lawyer and who have to go back time after time to get it done."

In this case, Thompson's client worked two jobs but was evicted from her apartment and needed money to pay for a down payment on a new place. Thompson was able to go to court and speak on his client's behalf so that she would not need to fear being incarcerated. Individuals who did not have an attorney may have had a different fate.

Some attorneys, Thompson noted, are not willing to take the time to attend the necessary court hearings to resolve debt and that unrepresented individuals fare even worse as they lack the expertise to properly communicate with the courts. Individuals who are deemed indigent do not have representation. Pro Bono Attorney Roberts remarked that "A lot of people have public defenders. But of course, they're only defending the state case." Individuals may, he said, "be incarcerated for the state case, but they could have a host of other warrants in other municipalities. And because the attorney is able to take care of those state cases, and we're only able to take care of the state case, they do the shuffle into different counties."

The fragmented system tasks lawyers with additional communication work, hampering their ability to efficiently and cost-effectively resolve outstanding debts and warrants. It is the complex parochial system that makes this more difficult-each municipal court sets its own lo- cal rules that attorneys must learn if they are to resolve debt. System impacted people receive even less information about how the courts operate. When this lack of information is coupled with performative aspects of attending court (such as arriving on time when there is little parking and dressing to judges' standards), resolving court debt becomes a near-impossible burden.

\section{LIMITED REMEDIES FOR}

\section{RESOLVING DEBT}

The finding of indigence is one way to mitigate the collateral consequences of monetary sanctions. State law in Missouri allows for the full waiver of fines, fees, and court costs in felony cases, something we observed with great regularity in court observations. Conversely, state laws offer little relief or guidance for individuals who cannot pay in municipal court. Although the reforms mandate assessment of the ability to pay in municipal courts and that individuals be offered community service in lieu of a financial sanction, legal actors felt that guidance on how to demonstrate indigence was minimal. One judge remarked that municipal courts seem to be overlooked and are not as sensitive to individuals' ability to pay as state cases: "I think the same, I don't want to say protections, but the same thought process or reason behind, find out if people can really afford to pay on the municipal should be the same way we look at state cases. I don't know why, it just hasn't developed that way. But I certainly think that should be the national progression." Judge Clark echoed a theme of frustration and bewilderment common in narratives. He did not understand why the system of justice was so different in the state and the municipal courts.

Some attorneys expressed frustration that the process of proving indigence is difficult for them, let alone any unrepresented individual. Defense Attorney Thompson felt that judges were not receptive to lowering or dismissing fines. The performative process required to prove their clients are unable to pay their debts is arduous, such that they attempt to obtain "support letters from the caseworkers they're working with and occasionally I'll drag the caseworkers on the court with me." To resolve the debt, Thompson said that they must "set a 
hearing so that we can convince the judge that our client cannot pay and that our client is not sitting on a stack of money somewhere just laughing at the court that they're actually struggling, that they're in poverty, that they have a situation that is beyond their control that was preventing them from being able to satisfy the obligation to the court." Attorneys can ask for an indigence hearing, but this mechanism is often unknown to individuals without representation.

The process of resolving court debt was so complicated that many individuals with court debt indicated that they worked with their probation officer to help navigate the system, but they often face similar roadblocks as their clients. Probation officers faced difficulty both locating the municipalities in which their clients owed debt and convincing other court actors of their clients' limited ability to pay. All of the probation officers interviewed reported that they will often reach out to municipalities to resolve their clients' debts, but have difficulty keeping track of individuals' progress because their clients often had debt managed by multiple courts and each court maintained different processes and policies. Probation Officer Philips explained it this way: "I think we've got a lot of officers who will reach out to different municipalities and say, "You've got a warrant out for this guy for failure to appear. Do you really want him because he's sitting in my office? But we've also got this and this going on with him." And a lot of times, they don't want them. They want them to show up to court and pay. But that's one more wrinkle in what we have to deal with because we've got to try to figure out where the line is at each municipality." In the end, some courts may be more forgiving when considering individuals' ability to pay. However, the expectation among the municipal courts is unclear, leaving defense attorneys and probation officers usually tasked with extra communication work to find out to whom the debt is owed and how it can be resolved.

Overall, the performative work of compliance was arduous. Several respondents in dicated that they simply gave up rather than continually engage with the court. Kevin, a fifty- one-year-old Black man, reported that he resolved a license suspension by waiting until the legal judgment against him expired. He explained that he would "just wait until ten years was up" to get his drivers' license back rather than fight with the courts because he could not afford representation. He explained the tiresome cycle of compliance with the municipal courts:

I was in a car accident and I was working and I had to go to court. I was working in a service station where I was in the booth. I was there by myself and I couldn't leave the booth. I miss a court day and when I went down there after work, and the judge said he was going to reschedule it, but they put me as defaulting and I had to pay for it. I had to get a SR22, I had to pay for the insurance in order to get my driver's license. Every time, say if I get employed and it elapse, I have to start all back over.

This narrative highlights the disproportionate and enduring costs of municipal sanctions, particularly for individuals without the means to pay or to hire legal counsel. Lack of state guidance on indigence has made the process of determining the ability to pay so difficult that individuals with legal debt avoid courts entirely and probation officers and attorneys spend an immense amount of time and resources convincing courts that their clients cannot pay.

\section{FRAGMENTED INFORMATION FLOW}

Participants routinely noted that a fundamental challenge to compliance is the lack of information available on a case. Before recent legislation, the state did not require municipalities to publish information on municipal court cases publicly nor did it maintain or fund an information portal for litigants; something that is a funded mandate for state courts. As part of recent legal reforms, the Office of State Court Administrators is developing a standardized data system. The reform comes at the cost to litigants; all municipal court cases are assessed a $\$ 7.00$ court automation fee, a cost not assessed for state cases. ${ }^{11}$ 
Many participants reported that they have trouble finding information about their cases and determining how much they owe (see also Supreme Court of Missouri 2016). Defense attorneys and individuals sentenced to debt said that this issue stems from the archaic methods courts use to notify individuals of their debt and from online data entry errors on the part of court staff that makes the case information inaccessible. For instance, individuals are still expected to rely on paper slips to keep informed about their debt and future court proceedings. Joaquin, a thirty-one-year-old Black man, described the process: "If you get help and go to court, and then they start your payment plan, then they'll give you a piece of paper with every month and day you have to come and pay it. Instead of just sending you a notice every month, they give it to you on a piece of paper." He went on to explain that if an individual were to lose that piece of paper, he was not aware of any way to look up future court dates. Defense Attorney Thompson described the process of information retrieval in detail: "If they owe money they're given a slip usually in the court that tells them how much money they're supposed to pay and when they're supposed to come back. If they lose that slip, then they can either call the court or now they can look online and some of the courts here report to municourt.net or they report to Municipal Court Records Search or they report to Case.net and you look on there and see how much fines you owe."

However, they also noted that although some municipal courts have moved to an online court record system, there are multiple portals for different communities, all based on different data systems, and the information is often misleading. Defense Attorney Thompson explained that the online system does not function as intended because courts will "auto-fill the presumed amount for that fine so even if the person hasn't pled guilty, it will show a fine amount on the public record." Individuals sentenced to debt have trouble tracking what they owe because the courts rely on paper slips handed out in court, fail to update the online system, do not provide reminders of court appearances, and do not communicate with one another.
Further, the lack of communication between courts can lead to additional sanctions. Several participants noted that they were given sanctions for failure to appear because they were incarcerated in another jurisdiction. Individuals are not routinely given a letter of incarceration; and the lack of a comprehensive database makes documenting the reason for missing court more difficult. Noah described his experience: "Well, before I got locked up I had set in the justice center for three days. Then I went to city court, and you know, they gave me a new court date. But I end up getting arrested for a probation violation like, before I could make that court date." Noah faced a host of potential sanctions because the systems were not connected.

In addition, few legal mandates consider accessibility to the courts or require frequent or regular hearings. None of the municipalities in St. Louis County hold court daily and some meet only once per month, which can seriously prolong the term of interaction with courts and make it difficult for people to attend court to resolve their legal financial obligations (Arch City Defenders 2014; Supreme Court of Missouri 2016). When observing courtrooms, research assistants for this project had difficulty finding courts. One municipal court, for example, was held in the basement of police department headquarters and city hall. Our observer found it tucked behind a residential area, with a For Sale sign on the side of it and with limited parking. Cars filled the small lot and lined the street, making parking difficult.

Finally, because of the decentralized nature of the courts, coupled with the lack of a central data system, participants often were not always aware of the agency that issued the ticket or where the court was located, and some participants lost their tickets. The lack of information on court cases increased the procedural costs associated with compliance. Individuals with legal debt discussed having to drive multiple places just to find the court. For example, Kevin, a twenty-year-old Black male, knew he had a ticket but was not sure where it was issued and did not know where to find the information on his case. He remarked, "I don't know whether Court A and Court B have the same courthouse building, so I'm going there today 
to make sure." Individuals without representation are tasked with keeping track of paper slips for payments and finding obscure court locations that meet only once a month.

In summary, the opaque nature of the municipal courts is difficult to navigate for litigants and decision-makers alike, and the system is allowed to flourish under the laissez-faire management of the state. A comment from a prosecutor exemplifies the phenomenon. When asked how they got this way, Prosecutor Anderson said, "I think for years and years and years they didn't pay attention to municipal courts. You didn't have anybody from the Supreme Court administrator, you didn't have anybody from the Supreme Court, you didn't even have your circuit judges. Didn't give a damn about municipal courts, just 'cause there's too many of them."

The municipal courts, he felt, have become too large and unruly to manage. We conclude that though the U.S. Department of Justice (2015) report on Ferguson provided an impetus to reduce the amount of revenue generated through municipal police and courts, the structure of the court system allows the same practices focused on revenue generation to continue.

\section{SUMMARY AND CONCLUSIONS}

The results from this analysis suggest that the larger systems of control, including parochial governance, have allowed the municipal courts to maintain a dominant role in many people's lives even after the state legislature placed limits on revenue collection. The problem is systemic, not necessarily driven by any master plan, and self-perpetuating as court actors and defendants have to come up with ways to cope with a system that emphasizes free-market exchange but also advancement through state and market powers that forcibly expropriate resources (Beckett and Murakawa 2012; Page and Soss 2017). As a result, municipalities continue to aggressively enforce traffic and ordinance violations, which disproportionately affect people of color. Those with legal debt are often shuffled from municipality to municipality, resulting in license suspension and warrants that further perpetuates the cyclic nature of criminal legal involvement. Even after reform, the sheer number of tickets for municipal infractions have declined in some communities, and others have folded, but most of the proposed reforms were symbolic in nature and others have not been achieved, such as expanding access to alternatives to monetary sanctions including community supervision (Forward through Ferguson 2018) and the patterns of revenue extraction persist in the region for governance and continue an age-old cycle that has disproportionate effects on people of color (Rios 2019).

At the same time, the municipal court system in Missouri, much like that observed in the rise of mass incarceration, has been allowed to continue-beyond the symbolic changeswithout intervention from political actors (Gottschalk 2006). Individuals who enter municipal courts are barred from the same legal protections given to those in felony courts (see also Huebner and Shannon 2022, this volume). We find that the decentralized nature and independence of the municipal courts fragments information flow about monetary sanctions among municipalities and to citizens, and the reforms that are designed to provide more access to court information come with a cost to those involved in the system. The parochial nature of the court is further supported by state legal structures. The Municipal Division Work Group to the Supreme Court of Missouri contends that the root cause of municipal tickets is that "state law that enables municipalities to profit financially from ordinance enforcement activities, and the judicial selection and retention procedures that expose the judges and court personnel to undue and improper pressure from the executive and legislative branches of municipal government" $(2016,26)$. In the end, although misdemeanor justice is a local phenomenon, larger structures at the state level act as a catalyst for individual control.

The results of the research are important for policy. One key theme that emerged was the call for restructuring or altogether elimination of the municipal courts. This refrain has been echoed by many local advocates and scholars (Arch City Defenders 2014; Boyles 2015; Ferguson Commission 2015). When asked to propose policy recommendations, Probation Officer Turner said, "I'd get rid of the munies." Prose- 
cutor Anderson echoed him: "people ought to be able to go one place for the municipal court in order to reduce confusion about what individuals' are charged with and what fines they owe." Anderson also contended that a centralized system would potentially decrease the disparities in punishment across communities and made note that consistency in punishment may breed compliance. We argue that centralization may improve public services by increasing information flow both between courts and to citizens, as demonstrated in other states with centralized court systems (see Verma and Sykes 2022, this volume). Easily accessible information about what is owed and to whom may reduce the number of missed court appearances leading to warrants.

However, policy reform will not affect outcomes and structural inequalities if they are symbolic. The fundamental structure of municipal funding was not changed as part of the reforms. Without altering the way that law enforcement and courts are funded, we cannot expect legal actors to find new avenues of financial support except by way of those who enter the system (Friedman et al. 2022, this volume). As Karin Martin et al. (2018) argues, the precarity of funding streams, particularly as it relates to the judicial branch, has led to short-sighted, "monetary myopia," when revenue takes priority over other community needs and goals. In the St. Louis region, the need for financial support of legal systems had resulted in some communities punishing their residents to keep afloat, a strategy that will further disadvantage the earnings and long-term success of community members, many of whom are people of color (Harding, Siegel, and Morenoff 2017).

The results from this work portend the need for systemic and cultural reform at the statutory, local community court, and judicial levels. However, structural change itself will not be successful unless judges are "applying standards in a manner consistent not only with the policy itself, but also with the principles that animated the policy reform" (Nagrecha, Brett, and Doyle 2020, 97-98). Reformers should look beyond simply changing the structure of the court and also consider the potential in a democracy-enhancing jurisprudence, which encourages judges to heed the calls made by local advocacy groups and to take an active role in considering and documenting the needs of litigants by writing opinions and writing new court rules that better reflect the need of constituents (Bell, Garlock, and Nabavi-Noori 2020).

\section{REFERENCES}

Arch City Defenders. 2014. Municipal Courts White Paper. St. Louis, Mo.: Arch City Defenders.

Atkinson, Rowland, and John Flint. 2001. "Accessing Hidden and Hard-to-Reach Populations: Snowball Research Strategies." Social Research Update 33(1): 1-4.

Beck, Brenden. 2019. "Broken Windows in the Culde-Sac? Race/Ethnicity and Quality-of-Life Policing in the Changing Suburbs." Crime \& Delinquency 65(2): 270-92.

Becker, Sarah. 2014. “'Because That's What Justice Is to Us': Exploring the Racialized Collateral Consequences of New Parochialism." Critical Criminology 22(2): 199-218.

Beckett, Katherine, and Naomi Murakawa. 2012. "Mapping the Shadow Carceral State: Toward an Institutionally Capacious Approach to Punishment." Theoretical Criminology 16(2): 22144.

Bell, Monica C. 2017. "Police Reform and the Dismantling of Legal Estrangement." Yale Law Journal 126(7): 2054-150.

Bell, Monica C., Stephanie Garlock, and Alexander Nabavi-Noori. 2020. “Toward a Demosprudence of Poverty." Duke Law Journal 69(7): 1473-527.

Biernacki, Patrick, and Dan Waldorf. 1981. "Snowball Sampling: Problems and Techniques of Chain Referral Sampling." Sociological Methods \& Research 10(2): 141-63.

Bing, Lindsay, Becky Pettit, and Ilya Slavinski. 2022. "Incomparable Punishments: How Economic Inequality Contributes to the Disparate Impact of Legal Fines and Fees." RSF: The Russell Sage Foundation Journal of the Social Sciences 8(2): 118-36. DOI: https://doi.org/10.7758/RSF .2022.8.2.06.

Blumer, Harold. 1954. "What Is Wrong with Social Theory?" American Sociological Review 19(1): 3-10.

Bonilla-Silva, Eduardo. 2010. Racism Without Racists: Color-Blind Racism and the Persistence of Racial Inequality in America. Lanham, Md.: Rowman and Littlefield. 
Boyles, Andrea. 2015. Race, Place, and Suburban Policing. Berkeley: University of California Press.

Cadigan, Michele, and Gabriella Kirk 2020. “On Thin Ice: Bureaucratic Processes of Monetary Sanctions and Job Insecurity." RSF: The Russell Sage Foundation Journal of the Social Sciences 6(1): 113-31. DOI: https://doi.org/10.7758/RSF.2020 6.1.05.

Carr, Patrick J. 2003. “The New Parochialism: The Implications of the Beltway Case for Arguments Concerning Informal Social Control." American Journal of Sociology 108(6): 1249-291.

Charmaz, Katherine. 2006. Constructing Grounded Theory: A Practical Guide through Qualitative Research. London: Sage Publications.

Colgan, Beth. 2018. "The Excessive Fines Clause: Challenging the Moden Debtors Prison." UCLA Law Review 652(2): 5-76.

Feeley, Malcolm M. 1979. The Process Is the Punishment: Handling Cases in a Lower Criminal Court. New York: Russell Sage Foundation.

Ferguson Commission. 2015. Forward Through Ferguson: A Path Toward Racial Equity. St. Louis, Mo.: Ferguson Commission. Accessed August 10, 2021. https://forwardthroughferguson.org/report /executive-summary.

Fernandes, April D., Michele Cadigan, Frank Edwards, and Alexes Harris. 2019. “Monetary Sanctions: A Review of Revenue Generation, Legal Challenges, and Reform." Annual Review of Law and Social Science 15(1): 397-413.

Fernandes, April D., Brittany Friedman, and Gabriela Kirk. 2022. “The 'Damaged' State vs. the 'Willful' Nonpayer: Constructing Damage, Harm and Willfulness Through Pay-to-Stay Lawsuits." RSF: The Russell Sage Foundation Journal of the Social Sciences 8(1): 82-105. DOI: https://doi.org/10.7758 /RSF.2022.8.1.04.

Forward Through Ferguson. 2018. The State of the Report: Tracking the Ferguson Commission's Calls to Action. St. Louis, Mo.: Forward through Ferguson.

Friedman, Brittany, Alexes Harris, Beth M. Huebner, Karin D. Martin, Becky Pettit, Sarah K.S. Shannon, and Bryan L. Sykes. 2022. "What Is Wrong with Monetary Sanctions? Directions for Policy, Practice, and Research." RSF: The Russell Sage Foundation Journal of the Social Sciences 8(1): 221-43. DOI: https://doi.org/10 .7758/RSF.2022.8.1.10.

Garland, David. 2001. The Culture of Control: Crime and Social Order in Contemporary Society. Chicago: University of Chicago Press.

Garrett, Brandon, Karima Modjadidi, and William Crozier. 2020. “Undeliverable: Suspended Driver's Licenses and the Problem of Notice." UCLA Criminal Justice Law Review 4(1): 186-98.

Gaston, Shytierra, and Rod K. Brunson. 2020. “Reasonable Suspicion in the Eye of the Beholder: Routine Policing in Racially Different Disadvantaged Neighborhoods." Urban Affairs Review 56(1): 188-227.

Glaser, Barney, and Anslem Strauss. 1967. "Grounded Theory: The Discovery of Grounded Theory." Sociology: The Journal of the British Sociological Association 12(1): 27-49.

Gordon, Colin. 2013. “Patchwork Metropolis: Fragmented Governance and Urban Decline in Greater St. Louis." Saint Louis University Public Law Review 34(6): 51-71.

- 2019. Citizen Brown: Race, Democracy, and Inequality in the St. Louis Suburbs. Chicago: University of Chicago Press.

Gottschalk, Marie. 2006. The Prison and the Gallows: The Politics of Mass Incarceration in America. Cambridge: Cambridge University Press.

Graham, Shannon R., and Michael D. Makowsky. 2021. “Local Government Dependence on Criminal Justice Revenue and Emerging Constraints." Annual Review of Criminology 4(1): 311-30.

Harding, David J., Jonah A. Siegel, and Jeffrey D. Morenoff. 2017. "Custodial Parole Sanctions and Earnings after Release from Prison." Social Forces 96(2): 909-34.

Harris, Alexes. 2016. A Pound of Flesh: Monetary Sanctions as Punishment for the Poor. New York: Russell Sage Foundation.

Harris, Alexes, Heather Evans, and Katherine Beckett. 2010. “Drawing Blood from Stones: Legal Debt and Social Inequality in the Contemporary United States." American Journal of Sociology 115(6): 1753-799.

Harris, Alexes, Mary Pattillo, and Bryan L. Sykes. 2022. "Studying the System of Monetary Sanctions." RSF: The Russell Sage Foundation Journal of the Social Sciences 8(1): 1-33. DOI: https://doi. org/10.7758/RSF.2022.8.1.01.

Hepburn, Peter, Issa Kohler-Hausmann, and Angela Zorro Medina. 2019. "Cumulative Risks of Multiple Criminal Justice Outcomes in New York City." Demography 56(3): 1161-171.

Huebner, Beth M., and Sarah K.S. Shannon. 2022. 
“Private Probation Costs, Compliance, and the Proportionality of Punishment: Evidence from Georgia and Missouri." RSF: The Russell Sage Foundation Journal of the Social Sciences 8(1): 179-99. DOI: https://doi.org/10.7758/RSF.2022 8.1.08.

Johnson, Walter. 2020. The Broken Heart of America:

St. Louis and the Violent History of the United States. New York: Basic Books.

Kirk, Gabriela, April D. Fernandes, and Brittany Friedman. 2020. “Who Pays for the Welfare State? Austerity Politics and the Origin of Payto-Stay Fees as Revenue Generation." Sociological Perspectives 63(6): 921-38.

Kohler-Hausmann, Issa. 2018. Misdemeanorland: Criminal Courts and Social Control in an Age of Broken Windows Policing. Princeton, N.J.: Princeton University Press.

Martin, Karin D. 2020. “Law, Money, People: Insights From a Brief History of Court Funding Concerns." UCLA Criminal Justice Law Review 4(1): 213-26.

Martin, Karin D., Kimberly Spencer-Suarez, and Gabriela Kirk. 2022. “Pay or Display: Monetary Sanctions and the Performance of Accountability and Procedural Integrity in New York and Illinois Courts" RSF: The Russell Sage Foundation Journal of the Social Sciences 8(1): 128-47. DOI: https://doi.org/10.7758/RSF.2022.8.1.06.

Martin, Karin D., Bryan L. Sykes, Sarah K.S. Shannon, Frank Edwards, and Alexes Harris. 2018. "Monetary Sanctions: Legal Financial Obligations in US Systems of Justice." Annual Review of Criminology 1(1): 471-95. DOI: https://doi.org /10.1146/annurev-criminol-032317-091915.

Mayson, Sandra, and Megan Stevenson. 2020. "Misdemeanors by the Numbers." Boston College Law Review 61(3): 973-1044.

Missouri Attorney General. 2020. 2019 Vehicle Stop Report. Jefferson City: Missouri Attorney General. Nagrecha, Mitali, Sharon Brett, and Colin Doyle. 2020. "Court Culture and Criminal Law Reform." Duke Law Journal 69 (April): 84-113.

Natapoff, Alexandra. 2018. Punishment Without Crime: How Our Massive Misdemeanor System Traps the Innocent and Makes America More Unequal. New York: Basic Books.

Office of State Court Administrator. 2020. 2019 Annual Statistical Report. Jefferson City: State of Missouri.

Pacewicz, Josh, and John N. Robinson III. 2021.
“Pocketbook Policing: How Race Shapes Municipal Reliance on Punitive Fines and Fees in the Chicago Suburbs." Socio-Economic Review 19(4): 975-1003. https://doi.org/10.1093/ser /mwaa029 (accessed August 8, 2021).

Page, Josh, and Joe Soss. 2017. “Criminal Justice Predation and Neoliberal Governance." In Rethinking Neoliberalism, edited by Sanford F. Schram and Marianna Pavlovskaya. New York: Routledge.

Pattillo, Mary, and Gabriela Kirk. 2020. “Pay Unto Caesar: Breaches of Justice in the Monetary Sanctions Regime." UCLA Criminal Justice Law Review 4(1): 50-75.

—. 2021. “Layaway Freedom: Coercive Financialization in the Criminal Legal System." American Journal of Sociology 126(4): 889-930.

Pleggenkuhle, Breanne. 2018. “The Financial Cost of a Criminal Conviction: Context and Consequences." Criminal Justice and Behavior 45(1): 121-45. DOI: https://doi.org/10.1177/0093854 817734278.

Rios, Jodi. 2019. “Racial States of Municipal Governance: Policing Bodies and Space for Revenue in North St. Louis County, MO." Law \& Inequality 37(2): 235-308.

Shannon, Sarah K.S., Beth M. Huebner, Alexes Harris, Karin D. Martin, Mary Pattillo, Becky Pettit, Bryan L. Sykes, and Christopher Uggen. 2020. "The Broad Scope and Variation of Monetary Sanctions: Evidence from Eight States." UCLA Law Review 4(1): 269-81.

Slavinski, llya, and Becky Pettit. 2021. “Proliferation of Punishment: The Centrality of Legal Fines and Fees in the Landscape of Contemporary Penology." Social Problems (January). spaa077. https:// doi.org/10.1093/socpro/spaa077 (accessed August 8, 2021).

Slocum, Lee Ann, Beth M. Huebner, Claire Greene, and Richard Rosenfeld. 2020. “Enforcement Trends in the City of St. Louis from 2007 to 2017: Exploring Variability in Arrests and Criminal Summonses over Time and across Communities." Journal of Community Psychology 48(1): 36-67.

Slocum, Lee Ann, Luis Torres, and Beth M. Huebner. 2020. Warrant Arrests in the City of St. Louis, 2002-2019. New York: Research Network on Misdemeanor Justice.

Smith, Tyler, Kristina J. Thompson, and Michele Cadigan. 2022. "Sensemaking in the Legal System: A Comparative Case Study of Changes to Mone- 
tary Sanction Laws." RSF: The Russell Sage Foundation Journal of the Social Sciences 8(1): 63-81. DOI: https://doi.org/10.7758/RSF.2022 8.1.03.

Stevenson, Megan, and Sandra Mayson. 2018. "The Scale of Misdemeanor Justice." Boston University Law Review 98(3): 731-78.

Supreme Court of Missouri. 2016. Report of the Municipal Division Work Group to the Supreme Court of Missouri. Jefferson City: Supreme Court of Missouri.

U.S. Census Bureau (Census Bureau). 2017. 2017 Census of Governments Organization. Washington: Government Printing Office. Accessed August 8, 2021. https://www.census.gov/data /tables/2017/econ/gus/2017-governments.html.

U.S. Department of Justice (DOJ). 2015. Investigation of the Ferguson Police Department. Washington: Government Printing Office.

Verma, Anjuli, and Bryan L. Sykes. 2022. “Beyond the Penal Code: The Corpus of Monetary Sanctions in California Law." RSF: The Russell Sage Foundation Journal of the Social Sciences 8(1): 36-62. DOI: https://doi.org/10.7758/RSF.2022 8.1.02.

Wacquant, Loïc. 2009. Punishing the Poor: Neoliberal Government and Social Insecurity. Durham, N.C.: Duke University Press.

Zettler, Haley R., and Robert G. Morris 2015. “An Exploratory Assessment of Race and GenderSpecific Predictors of Failure to Appear in Court Among Defendants Released via a Pretrial Services Agency." Criminal Justice Review 40(4): 417-30. 